\title{
PENGEMBANGAN VIDEO PEMBELAJARAN FISIKA CHANNEL YOUTUBE BERBANTU APLIKASI POWTOON PADA MATERI SUHU DAN KALOR
}

\author{
Amirul Anam ${ }^{1 *}$, Widya Wati ${ }^{1}$, Nur Asiah ${ }^{1}$ \\ ${ }^{1}$ Universitas Islam Negeri Raden Intan Lampung \\ *corresponding author: amirulanam0912@gmail.com
}

\section{Article History:}

Received: januari 07, 2020

Revised: februari 13, 2020

Accepted: mei 21, 2020

Published: juni 30, 2020

Keywords:

Video

Pembelajaran, Channel

Youtube, Aplikasi Powtoon

\begin{abstract}
This research aims to produce physics learning videos on the YouTube channel assisted by Powtoon application on temperature and heat subject that meets valid criteria. To make learning interesting, learning videos need to be developed, one of the interesting learning videos is the Physics Learning Video on the YouTube Channel assisted by the Powtoon application. The research method used in this research is Research and Development with the Borg and Gall model. Based on the results of the research, the validity score of the Learning Video assisted by the Powtoon application based on expert judgment is in very valid criteria, with the percentage of validation from media experts is $84 \%$, from material experts $92 \%$, and IT experts $89 \%$. Teachers and students responded positively to the attractiveness of Learning Videos assisted by the Powtoon application as a learning media, with the percentage of teacher response scores reaching 85\%, small group tests 79\%, and field test results $82 \%$. Development of Learning Videos assisted by the Powtoon application is very valid and gets positive responses to be used as learning media.
\end{abstract}

\begin{abstract}
Abstrak: Penelitian ini bertujuan untuk menghasilkan video pembelajaran fisika channel youtube berbantu aplikasi powtoon materi suhu dan kalor yang memenuhi kriteria valid. Untuk mewujudkan pembelajaran yang menarik perlu dikembangkannya video pembelajaran, salah satu video pembelajaran yang menarik adalah Video Pembelajaran Fisika Channel Youtube berbantu aplikasi Powtoon. Metode penelitian yang digunakan dalam penelitian ini adalah menggunkan model Borg and Gall. Hasil penelitian yang didapatkan adalah kevalidan Video Pembelajaran berbantu aplikasi Powtoon berdasarkan penilaian ahli dikriteriakan sangat valid, dengan persentase validasi ahli media $84 \%$, ahli materi $92 \%$ serta ahli IT $89 \%$. Pendidik dan peserta didik memberikan respon positif terhadap kemenarikan Video Pembelajaran berbantu aplikasi Powtoon sebagai media pembelajaran, dengan persentase respon pendidik $85 \%$, uji kelompok kecil 79\%, dan uji lapangan $82 \%$. Pengembangan Video Pembelajaran berbantu aplikasi Powtoon sangat valid dan mendapatkan respon positif untuk dijadikan sebagai media pembelajaran.
\end{abstract}

\section{PENDAHULUAN}

Perkembangan

informasi dan komunikasi (TIK)

berkembang sangat cepat keseluruh pelosok dunia (Prabowo \& Arofah, 2017; Widayanti, Abdurrahman, \& Suyatna, 2019). Teknologi informasi dan komunikasi bukan lagi milik orang-orang tertentu melainkan milik semua orang mulai dari lapisan bawah hingga teratas (Yuberti, 2015). Bahkan perkembangannya diperkirakan lebih cepat dari perkiran semula, beberapa tahun yang lalu teknologi informasi dan komunikasi seperti komputer dan telepon seluler bebasis web masih terbilang produk mahal dan hanya dimiliki orangorang tertentu (Ahmad, 2018; Gunawan, 
Harjono, Sahidu, \& Gunada, 2019; Putro \& Litouw, 2018). Tetapi saat ini, teknologi tidak lagi hanya milik orangorang tertentu tetapi milik semua orang dari lapisan terendah sampai lapisan teratas (Irawan \& Surjono, 2018; Shamad, 2017), bahkan banyak orang yang tidak dapat terlepas dari teknologi tersebut dalam kesehariannya, mulai dari pagi sampai petang, bahkan dari bangun tidur sampai tidur lagi (Budiman, 2017; Nasution, 2017). Sebagian besar teknologi digunakan pada media sosial (Fauzi \& Lubis, 2016; Irwandani, 2016).

Penggunaan media sosial di indonesia sangat tinggi, terutama penggunaan media sosial seperti Facebook, Instagram, dan YouTube (Mahendra, 2017; Nugroho \& Ruwanto, 2017; Sofyani Wigati, 2015). Pengguna YouTube berjumlah 14,5 juta pengguna (Kominfo, 2014). Teknologi informasi salah satu faktor yang menyebabkan perubahan gaya hidup manusia dalam melakukan interaksi ke dunia luar (Sulistyono, 2016). Pengaruh teknologi informasi ini terjadi dalam berbagai bidang, baik itu dalam bidang sosial, ekonomi, budaya, dan bahkan dalam bidang pendidikan (Fero Bayu Saputro, 2017).

Pendidikan perlu mengintegrasikan dengan teknologi agar mempermudah siswa dalam memahami materi (Budiman, 2017). Terutama pada materi yang ada dalam kehidupan sehari-hari (Saregar, 2016). Suhu dan kalor erat dengan kehidupan, namun banyak yang tidak menyadari bahwa yang dilakukan salah satu penerapan materi suhu dan kalor $(\mathrm{P}$, H, \& Wisodo, 2016; Sayyadi, Hidayat, \& Muhardjito, 2016).

Beberapa peneliti telah menjelaskan materi suhu dan kalor dengan berbagai cara, dengan menerapkan model pembelajaran tertentu (Adhim \& Jatmiko, 2015; Sayyadi et al., 2016), pengembangan perangkat pembelajaran (Diani, 2015), penggunaan multimedia interactive (Husein, Herayanti, \& Gunawan, 2015) dan pengembangan bahan ajar (Paramita, Rusilowati, \& Semarang, 2016).

Fokus pada penelitian ini mengembangkan media pembelajaran suhu dan kalor menggunakan aplikasi Powtoon berbasis Youtube.

\section{METODE PENELITIAN}

Penelitian ini menggunakan metode penelitian dan pengembangan (Research \& Development) diadaptasi dari Borg and Gall dengan langkahlangkah sebagai berikut:

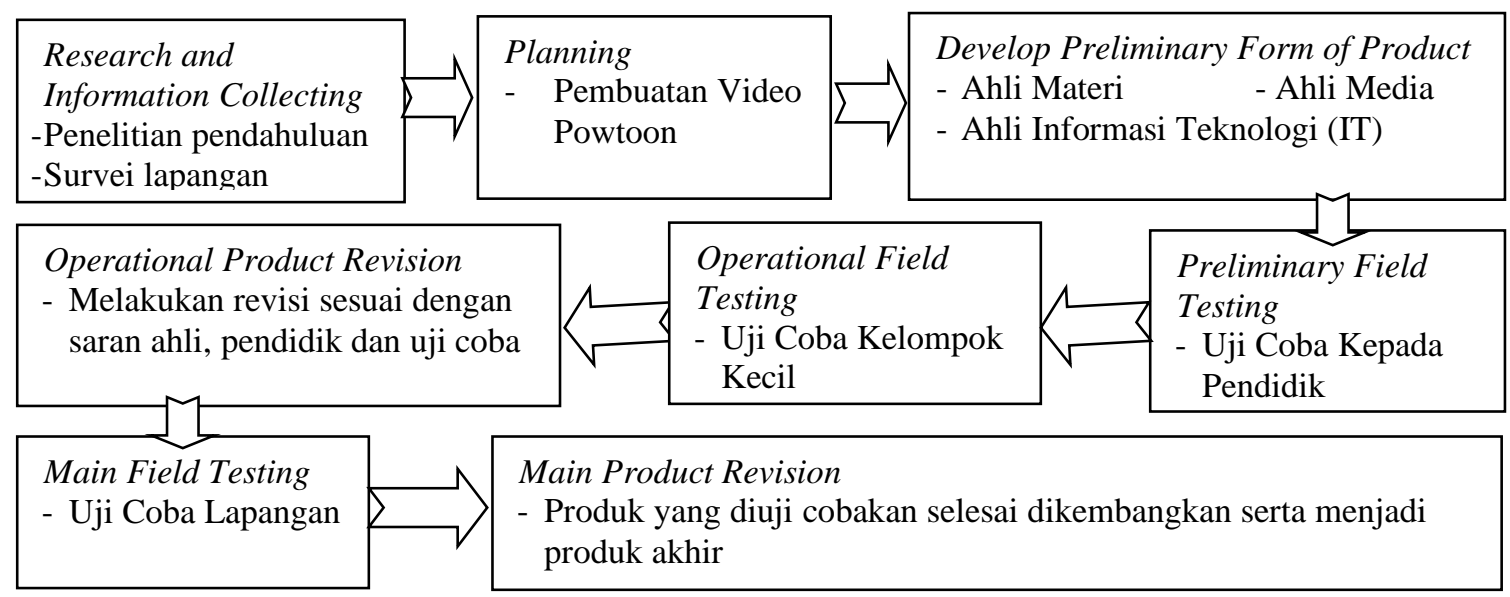

Gambar 1. Langkah-Langkah Penelitian 
Pada model borg dan gall terdapat sepuluh Langkah. Namun pada penelitian ini dilakukan delapan Langkah, karena penelitian ini ingin mengembangkan produk pembelajaran tanpa menyebarkan dan mengimplementasikan secara luas. Pengumpulan data dilakukan dengan menggunakan instrumen non tes berupa lembar validasi ahli materi, ahli media, ahli IT, Uji Coba kepada Pendidik serta respon peserta didik. Instrumen yang digunakan berupa kuesioner dengan Skala Likert (Agustian, 2013)

Pada penelitian ini menggunakan skala 1 sampai 5 dengan skor tertinggi 5 dan skor terendah 1. Persentase kriteria validasi diuraikan pada Tabel 1 .

Tabel 1 Skala Interpretasi Kriteria (Diani, Rahma

\begin{tabular}{lc}
\multicolumn{2}{c}{$\&$ Syarlisjiswan, 2018) } \\
\hline \multicolumn{1}{c}{ Kriteria } & Interval \\
\hline Sangat Valid & $0<\mathrm{X} \leq 20 \%$ \\
Tidak Valid & $20<\mathrm{X} \leq 40 \%$ \\
Cukup Valid & $40<\mathrm{X} \leq 60 \%$ \\
Valid & $60<\mathrm{X} \leq 80 \%$ \\
Sangat Valid & $80<\mathrm{X} \leq 100 \%$ \\
\hline
\end{tabular}

\section{HASIL DAN PEMBAHASAN HASIL}

Video pembelajaran fisika sebagai media pembelajaran disekolah merupakan potensi dari peneitian ini. Adanya video pembelajaran peserta didik dapat berperan aktif dalam pembelajaran dikelas. Penggunaan video pembelajaran dapat menambah antusias peserta didik serta memudahkan dalam memahami materi pelajaran yang ada disekolah.

Pada penelitian ini masalah yang ditemukan dilapangan yaitu pendidik kurang memaksimalkan penggunaan media untuk proses pembelajaran sehingga peserta didik merasa bosan dan kurang memahami materi pembelajaran yang hanya berbantu media buku cetak serta metode ceramah yang digunakan oleh pendidik pada kegiatan pembelajaran yang dilakukan dikelas sehingga peneliti mengembangkan Video Pembelajaran
Fisika Channel Youtube berbantu aplikasi Powtoon pada materi Suhu dan Kalor untuk SMP N 21 Bandar Lampung, SMP N 19 Bandar Lampung dan MTs Al Hikmah Bandar Lampung.

Langkah berikutnya yaitu mengumpulkan informasi sebagai solusi dari penelitian dan pengembangan yang dilakukan oleh peneliti. Informasi yang terkumpul digunakan sebagai acuan dalam memprediksi kebutuhan peserta didik terhadap video pembelajaran yang akan dikembangkan. Langkah pertama yang dilakukakn adalah mengumpulkan masalah di SMP N 21 Bandar Lampung, SMP 19 Bandar Lampung, dan MTs AlHikmah Bandar Lampung. Langkah berikutnya adalah mengumpulkan referensi antara lain artikel dari jurnal yang berhubungan dengan pengembangan video pembelajaran Fisika Channel Youtube berbasis aplikasi Powtoon.

Informasi yang telah terkumpul baik dari beberapa artikel jurnal, buku dan internet, langkah berikutnya adalah menciptakan video pembelajaran Fisika berbantu aplikasi Powtoon. Hasil produk video pembelajaran Fisika berbantu aplikasi Powtoon disajikan pada gambar berikut:

a. Membuat opening untuk video pembelajaran Fisika

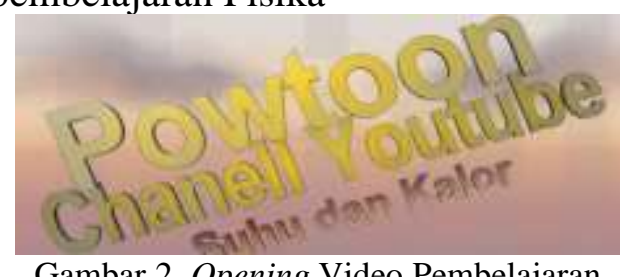

Gambar 2. Opening Video Pembelajaran

b. Membuat desain video pembelajaran powtoon materi suhu

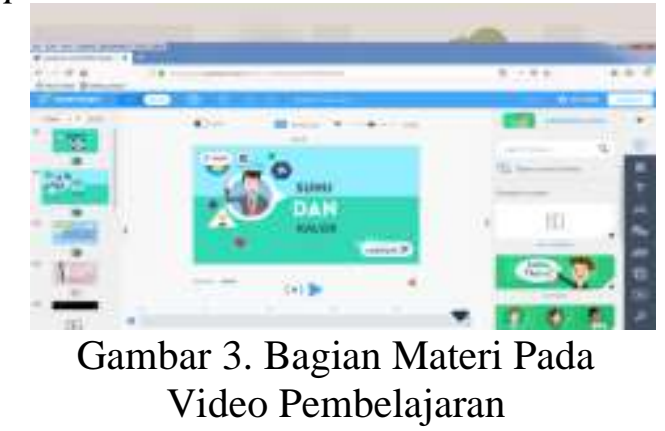


c. Membuat desain materi kalor

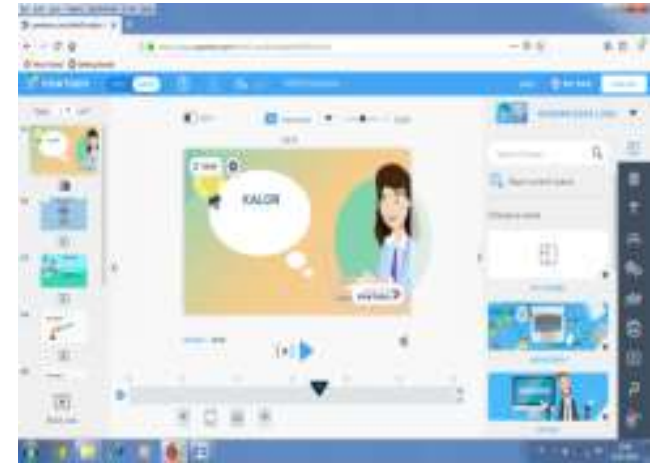

Gambar 4. Desain Materi Pada Video

d. Membuat desain penutup video pembelajaran

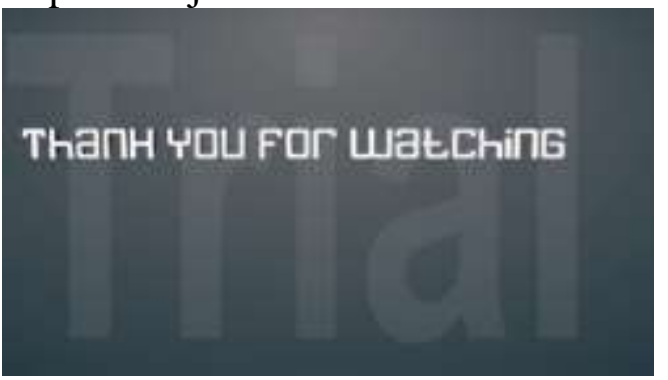

Gambar 5. Penutup Video Pembeajaran

Setelah produk berhasil dibuat maka pada tahap selanjutnya yaitu pengembangan. Tahap pengembangan produk diuji kevalidannya yang dilakukan oleh tim validator yang sudah ahli dalam bidangnya masing-masing. Tim validator berjumlah 5 ahli yaitu 2 ahli materi, 2 ahli media dan 1 ahli IT.

Berdasarkan penilaian yang dilakukan oleh ahli materi dapat diketahui bahwa pada aspek 1 mengenai kualitas isi mendapatkan persentase valid sebesar $83 \%$. Sedangkan pada aspek 2 yaitu keakuratan materi memperoleh persentase sebesar $84 \%$. Pada aspek 3 yaitu Kemutahiran Materil yaitu mendapatkan persentase sebesar $87 \%$. Rata-Rata penilaian yang dilakukan oleh tim ahli materi pada tahap 1 mengenai kevalidan materi mendapatkan persentase sebesar $84 \%$ dengan Kriteria Valid. Selanjutnya untuk penilaian ahli materi setelah revisi yaitu pada aspek 1 mengenai kualitas isi mendapat persentase sebesar $88 \%$.
Sedangkan pada tahap 2 yaitu keakuratan materi dan materi memperoleh persentase sebesar 94\%. Sedangkan pada aspek 3 yaitu kemutahiran materi yaitu memperoleh persentase sebesar 93\%. Rata-rata penilaian oleh validator ahli materi pada tahap revisi mendapatkan persentase valid yaitu sebesar 92\% dengan kriteria Sangat valid. Data dari analisis hasil penilaian validasi ahli materi dapat dilihat pada Gambar 6.

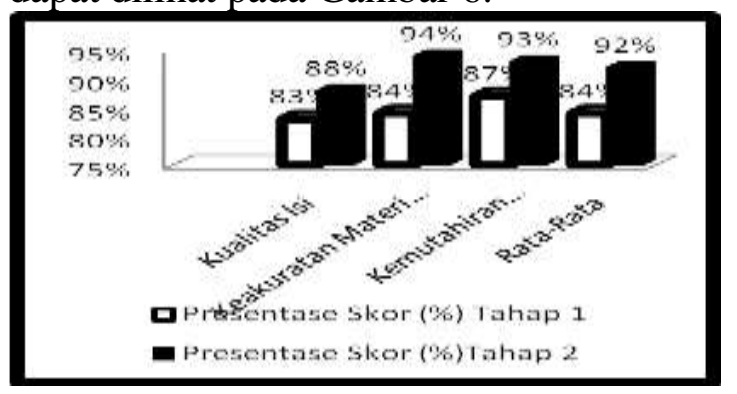

Gambar 6. Persentase Penilaian Ahli Materi

Berdasarkan penilaian yang dilakukan oleh ahli media dapat diketahui bahwa pada aspek 1 mengenai Tampilan Media mendapatkan persentase valid sebesar $75 \%$. Sedangkan pada aspek 2 yaitu kemenarikan media memperoleh persentase sebesar $73 \%$. Pada aspek 3 yaitu Kemudahan Penggunaan yaitu mendapatkan persentase sebesar $75 \%$. Rata-Rata penilaian yang dilakukan oleh tim ahli media pada tahap 1 mengenai kevalidan media mendapatkan persentase sebesar 74\% dengan Kriteria Sangat valid. Selanjutnya untuk penilaian ahli media setelah revisi yaitu pada aspek 1 mengenai Tampilan Media mendapat persentase sebesar $85 \%$. Sedangkan pada tahap 2 yaitu kemenarikan media memperoleh persentase sebesar $83 \%$. Sedangkan pada aspek 3 yaitu kemudahan Penggunaan yaitu memperoleh persentase sebesar $85 \%$. Rata-rata penilaian oleh validator ahli media pada tahap revisi mendapatkan persentase kevalidan yaitu sebesar 84\% dengan kriteria Sangat Valid. Data dari analisis hasil penilaian validasi ahli Media dapat dilihat pada Gambar 7. 


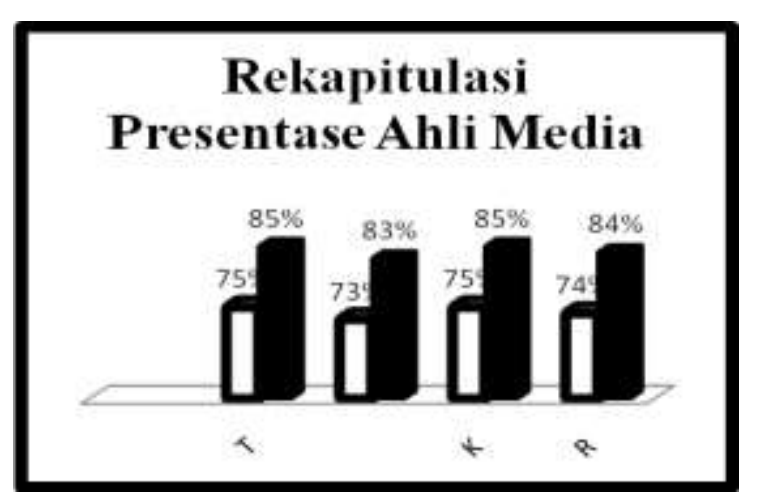

Gambar 7. Persentase Penilaian Ahli Media

Berdasarkan penilaian yang dilakukan oleh ahli IT dapat diketahui bahwa pada aspek 1 mengenai Kevalidan Isi mendapatkan persentase kevalidan sebesar 93\%. Sedangkan pada aspek 2 yaitu pewarnaan memperoleh persentase sebesar $87 \%$. Pada aspek 3 yaitu Penekanan pada Huruf (Font) yaitu mendapatkan persentase sebesar $83 \%$. Pada aspek 4 tentang kualitas gambar dan video memperoleh persentase sebesar $87 \%$. Pada aspek 5 tentang kualitas suara memperoleh persentase sebesar 93\%. Rata-Rata penilaian yang dilakukan oleh tim ahli IT mengenai kevalidan produk mendapatkan persentase sebesar $89 \%$ dengan Kriteria Sangat Valid. Data dari analisis hasil penilaian validasi ahli IT dapat dilihat pada Gambar 8.

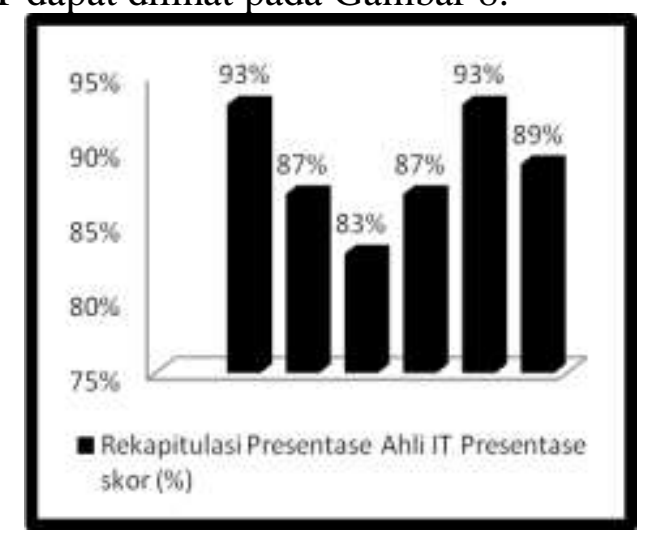

Gambar 8. Persentase Hasil Penilaian IT

Berdasarkan rekapitulasi hasil uji coba kepada pendidik yang dilakukan pada tiga pendidik mata pelajaran fisika di tiga sekolah. Hasil uji pend pada aspek 1 mengenai tampilan media yaitu memperoleh persentase sebesar $87 \%$. Pada aspek 2 mengenai penggunaan Powtoon memperoleh persentase sebesar $84 \%$. Pada aspek 3 mengenai petunjuk penggunaan memperoleh persentase sebesar $87 \%$. Sedangkan pada aspek 4 mengenai kesesuaian gambar memperoleh persentase sebesar $73 \%$. Pada aspek 5 penggunaan bahasa dalam Powtoon memperoleh persentase sebesar $89 \%$ serta pada aspek 6 pemberian materi memperoleh persentase sebesar $89 \%$, serta pada Rata-rata persentase diperoleh 85\% dengan Kriteria Sangat Baik. Data dari hasil analisis uji kepada pendidik dapat dilihat pada Gambar 9.

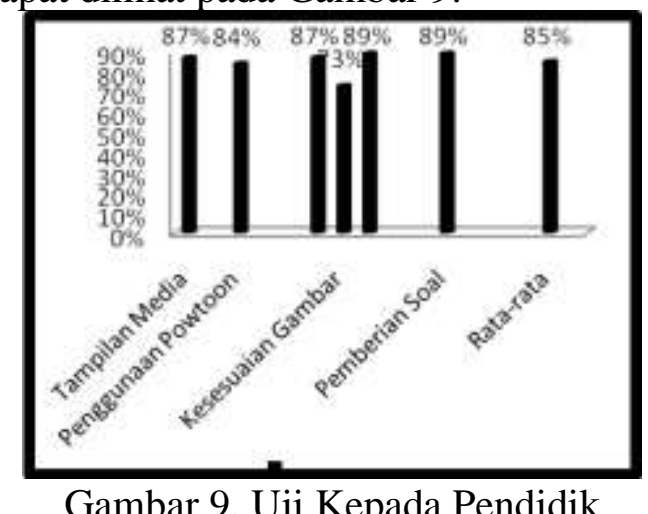

Berdasarkan rekapitulasi hasil uji kelompok kecil yang dilakukan pada 30 peserta didik pada mata pelajaran fisika di tiga sekolah. Hasil uji kelompok kecil pada aspek 1 mengenai tampilan media jumlah rata-rata skor 4 dengan perolehan persentase sebesar $79 \%$. Pada aspek 2 mengenai penggunaan Powtoon jumlah rata-rata skor 4 dengan perolehan persentase sebesar $80 \%$. Pada aspek 3 mengenai Kemanfaatan jumlah rata-rata skor 4 dengan perolehan persentase sebesar $78 \%$. Sedangkan pada aspek 4 mengenai Rasa Ingin Tahu jumlah ratarata skor 4 dengan perolehan persentase sebesar $80 \%$. Pada aspek 5 mengenai Menarik jumlah rata-rata skor 3,9 dengan perolehan persentase sebesar $78 \%$. Pada aspek 6 penggunaan bahasa dalam Powtoon jumlah rata-rata skor 4 dengan 
perolehan persentase sebesar $79 \%$. Sedangkan pada aspek 7 pemberian materi jumlah rata-rata skor 4 dengan perolehan persentase sebesar $80 \%$. Ratarata hasil penilaian uji kelompok kecil yang diberikan oleh 30 peserta didik pada tiga sekolah jumlah skor per Aspek 35 dengan rata-rata skor per aspek yaitu 4 dengan perolehan persentase sebesar $79 \%$ dengan kriteria Baik. Data dari hasil analisis uji kelompok kecil dapat dilihat pada Gambar 10.

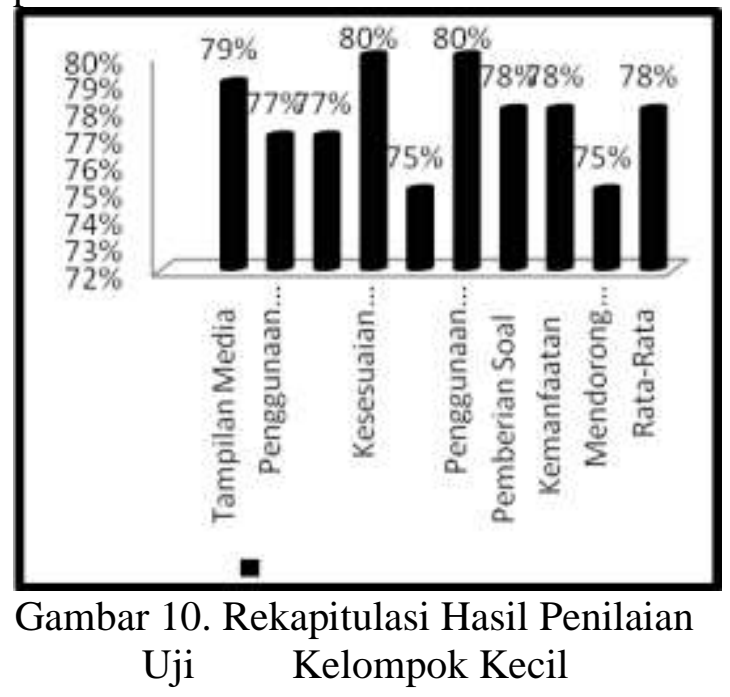

Berdasarkan hasil rekapitulasi hasil uji Coba Lapangan yang dilakukan pada 89 peserta didik pada mata pelajaran fisika di tiga sekolah. Hasil uji coba lapangan pada aspek 1 mengenai tampilan media jumlah rata-rata skor 4,1 dengan perolehan persentase sebesar $82 \%$. Pada aspek 2 mengenai penggunaan Powtoon jumlah rata-rata skor 4,1 dengan perolehan persentase sebesar $82 \%$. Pada aspek 3 mengenai Kemanfaatan jumlah rata-rata skor 4 dengan perolehan persentase sebesar $80 \%$. Sedangkan pada aspek 4 mengenai Rasa Ingin Tahu jumlah rata-rata skor 4,3 dengan perolehan persentase sebesar $87 \%$. Pada aspek 5 mengenai Menarik jumlah ratarata skor 4 dengan perolehan persentase sebesar $80 \%$. Pada aspek 6 penggunaan bahasa dalam Powtoon jumlah rata-rata skor 4 dengan perolehan persentase sebesar $82 \%$. Sedangkan pada aspek 7 pemberian materi jumlah rata-rata skor 4 dengan perolehan persentase sebesar $81 \%$. Rata-rata hasil penilaian uji coba lapangan yang diberikan oleh 89 peserta didik pada tiga sekolah jumlah skor per Aspek dengan rata-rata skor per aspek yaitu 4,1 dengan perolehan persentase sebesar $82 \%$ dengan kriteria Sangat Baik. Data dari hasil analisis uji coba lapangan dapat dilihat pada Gambar 11.

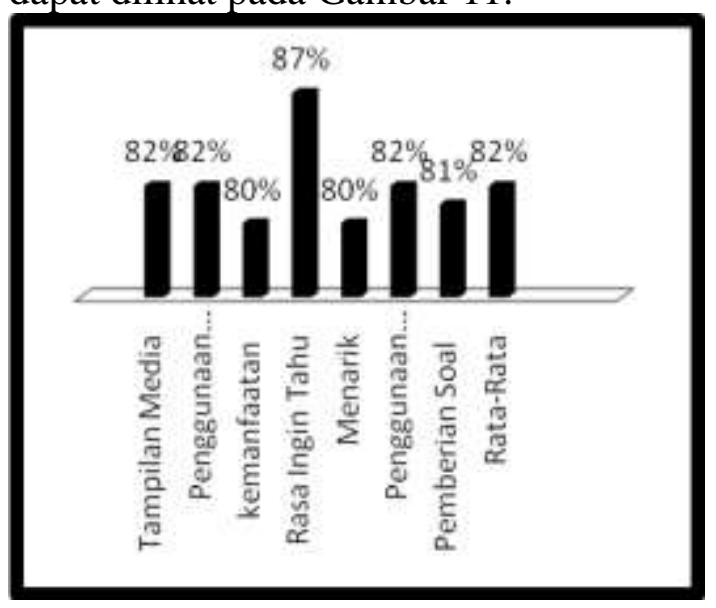

Gambar 11. Uji Coba Lapangan

\section{PEMBAHASAN}

Pengembangan proses penelitian yang diterapkan oleh peneliti menggunakan model Borg and Gall (Sugiyono, 2018). Tahap awal pada penelitian ini melakukan pra penelitian yang dilakukan pada tiga sekolah. Hasil pra penelitian yang dilakukan diketahui bahwa dari 3 sekolah masih belum memaksimalkan penggunaan media untuk proses pembelajaran sehingga peserta didik merasa bosan untuk mengikuti pembelajaran dikelas.

Tahap kedua yaitu dari hasil pra penelitian yang telah diketahui peneliti mencoba mengembangkan media yang menarik untuk proses pembelajaran. Menetapkan materi yang akan dipergunakan dalam video pembelajaran. Produk yang dikembangkan diharapkan dapat membantu serta memudahkan dalam proses pembelajaran.

Video yang berhasil dikembangkan kemudian dilakukanlah validasi kepada validator sebelum diujicobakan di 
lapangan. Validasi dilakukan oleh ahlimateri, ahlimedia dan ahli IT yang sudah ahli pada bidangnya masingmasing.

1. Hasil Validasi Produk Ahli Materi

Pengembangan video pembelajaran fisika sudah divalidasi kevalidannya yang dilakukan oleh dua validator ahli materi dan dinyatakan Sangat Valid dengan beberapa masukan yaitu seperti penambahan dalam contoh dalam kehidupan sehari-hari, penambahan referensi pada akhir video, penambahan macam-macam skala pada termometer serta penambahan durasi pada video yang terlalu cepat sehingga belum sempat selesai membacanya.

Validasi ahli materi saat dilakukan validasi memperoleh saran dan masukan yang diberikan oleh validator untuk perbaikan produk yang lebih baik. Produk yang telah direvisi sesuai dengan saran dan masukan yang telah diberikan oleh validator. Penilaian produk yang telah direvisi dari ahli materi mendapatkan persentase kevalidan sebesar $92 \%$ dengan kriteria Sangat Valid karena sudah sesuai dengan materi suhu dan kalor terhadap tujuan pembelajaran serta penjelasan materi suhu dan kalor yang sudah lengkap dan keakuratan konsep, definisi, simbol serta rumus fisika sudah sesuai sehingga media yang telah dikembangkan telah sesuai dengan materi suhu dan kalor sehingga valid di pergunakan untuk proses pembelajaran.

\section{Hasil Validasi Produk Ahli Media}

Pengembangan video pembelajaran fisika sudah divalidasi kevalidannya yang dilakukan oleh dua validator ahli media dan dinyatakan Sangat Valid dengan beberapa masukan yaitu seperti pembuatan skenario pada video pembelajaran serta keunggulan dari video pembelajaran fisika yang dikembangkan.

Validasi yang dilakukan oleh 2 orang validator memperoleh saran dan masukan oleh ahli media. Setelah saran dan masukan yang diberikan maka produk direvisi. Produk yang telah direvisi mendapatkan persentase kevalidan sebesar 84\% dengan kriteria Sangat Valid dikarenakan produk tersebut sudah memenuhi kriteria yaitu, penulisan font dalam media powtoon sudah sesuai, kesusuaian tata letak gambar dalam media powtoon sudah baik, serta dalam video powtoon tersebut menarik dan dapat digunakan untuk proses pembelajaran.

\section{Hasil Validasi Produk Ahli IT}

Validasi yang dilakukan oleh seorang validator sesuai dengan ahlinya memperoleh saran dan masukan pada produk yang dikembangkan. Produk direvisi sesuai dengan saran dan masukan yang diberikan oleh validator sehingga hasil dari produk yang telah direvisi memperoleh persentase kevalidan sebesar 89\% dan dikategorikan Sangat Valid karena dalam video pembelajaran tersebut perpaduan warna pada video dan pada back ground sangat baik, ukuran gambar yang terdapat dalam video tersebut sudah sesuai kapasitas yang diguankan, serta kejelasan dan volume suara dalam video tersebut sudah baik, sehingga produk yang berhasil dikembangkan siap untuk diperlihatkan kepada peserta didik.

\section{Uji Coba Kepada Pendidik}

Uji coba kepada pendidik mata pelajaran fisika di SMP N 21 Bandar Lampung, SMP N 19 Bandar Lampung dan MTs Al-Hikmah Bandar Lampung. Uji coba kepada pendidik ini diawali dengan peneliti menjelaskan kepada pendidik kemudian pendidik diminta untuk menilai dan memberikan tanggapan terhadap video pembelajaran fisika yang dikembangkan.

Berdasarkan uji coba dan analisis dari ke tiga pendidik terhadap pengembangan video pembelajaran sudah menarik sehingga dapat dipergunakan dijenjang SMP/MTs. Uji kepada pendidik yang dilakukan dapat diketahui dari hasil 
rata-rata persentase yang diperoleh yaitu sebesar $85 \%$ dengan hasil Sangat Baik dan dapat digunakan untuk proses pembelajaran.

\section{Uji Coba Produk}

Uji coba meliputi uji kelompok kecil dan uji coba lapangan terhadap video pembelajaran fisika yang dikembangkan. Uji kelompok kecil dilakukan pada 30 peserta didik pada 3 sekolah dan peserta didik diminta untuk mengisi angket yang diberikan oleh peneliti. Pada uji kelompok kecil mendapatkan persentase rata-rata sebesar $79 \%$ dengan kriteria Baik.

Pada uji coba lapangan yang dilakukan pada 89 peserta didik pada tiga sekolah yang sama dan dengan cara yang sama dari 7 aspek yang ada pada angket rata-rata persentase dari tiga sekolah yaitu sebesar 82\% dengan Kriteria "Sangat Baik". Berdasarkan uji coba yang telah dilakukan maka peneliti dapat melihat bahwa antusias peserta didik terhadap video pembelajaran fisika pada materi yang dikembangkan oleh peneliti yaitu sangat baik.

Sesuai dengan penelitian sebelumnya bahwa media pembelajaran sangat membantu dalam menjelaskan materi dan perlu di kembangkan pada setiap materi (Sari \& Gunawan, 2018; Sulfemi \& Mayasari, 2019; Widayanti \& Yuberti, 2018). Temuan pada penelitian ini bahwa pengembangan media berupa powtoon channel layak untuk diterapkan pada pembelajaran guna mempermudah siswa memahami materi suhu dan kalor.

\section{KESIMPULAN}

Dengan menggunakan langkah penelitian dan pengembangan model Borg and Gall telah berhasil dikembangkan video pembelajaran fisika Channel Youtube berbantu aplikasi powtoon pada materi suhu dan kalor. 1) Hasil validasi ahli materi mendapatkan rata-rata persentase sebesar $92 \%, 2$ ) hasil validasi ahli media mendapatkan rata-rata persentase sebesar $84 \%$. 3) Hasil ahli IT mendapatkan ratarata persentase sebesar $89 \%$. 4) Hasil uji telaah pakar yang dilakukan oleh pendidik mata pelajaran fisika di SMA mendapatkan persentase rata-rata skor sebesar 85\%. 5) Hasil persentase skor rata-rata pada uji coba kelompok kecil yaitu mendapat persentase sebesar $78 \%$ serta pada uji coba lapangan mendapatkan rata-rata persentase skor sebesar $82 \%$ dengan kategori "Sangat Menarik".

\section{DAFTAR PUSTAKA}

Adhim, A. Y., \& Jatmiko, B. (2015). Penerapan Model Pembelajaran Guided Discovery dengan Kegiatan Laboratorium Untuk meningkatkan Hasil Belajar Siswa Kelas X Pada Materi Suhu dan Kalor. Jurnal Inovasi Pendidikan Fisika (JIPF), 4(3), 77-82.

Agustian, N. O. (2013). Pembuatan Bahan Ajar Fisika Berbasis Web Menurut Standar Proses Siswa Kelas XI SMA. Pillar of Physics Education, 2. Ahmad, I. (2018). Proses Pembelajaran Digital dalam Era Revolusi Industri 4 . 0 Era Disrupsi Teknologi. Kementerian Riset, Teknologi, Dan Pendidikan Tinggi, 1-13.

Budiman, H. (2017). Peran Teknologi Informasi dan Komunikasi dalam Pendidikan. Al-Tadzkiyyah: Jurnal Pendidikan Islam, 8, 75-83.

Diani, Rahma, Y., \& Syarlisjiswan, M. R. (2018). WEB-Enhanced Course Based On Problem Learning (PBL): Development Of Interactive Learning Media For Basic Physics II. Jurnal Ilmiah Pendidikan Fisika AlBiRuNi, $7(1)$. https://doi.org/10.24042/jipfalbiruni. v7i1.2849

Diani, R. (2015). Pengembangan Perangkat Pembelajaran Fisika Berbasis Pendidikan Karakter dengan Model Problem Based 
Instruction. Jurnal Ilmiah Pendidikan Fisika Al-Biruni, 4(2), 243.

https://doi.org/10.24042/jpifalbiruni. v4i2.96

Fauzi, V. P., \& Lubis, E. E. (2016). Utilizing Instagram as Er-Corner Boutique's Media Marketing in Building Brand Awareness in Pekanbaru City. Journal Online Mahasiswa Fakultas Ilmu Sosial Dan Ilmu Politik, 3(1), 1-15.

Fero Bayu Saputro, M. S. and agung N. (2017). Pengembangan Sistem Kuliah Online Universitas Diponegoro Untuk Antar muka Mahasiswa Pada perangkat bergerak berbasis android. Transmisi, 19(1).

Gunawan, G., Harjono, A., Sahidu, H., \& Gunada, I. W. (2019). Pelatihan Pemanfaatan Teknologi Informasi Bagi Guru IPA Fisika Di Lombok Barat. Jurnal Pendidikan Dan Pengabdian Masyarakat, 2(1).

Husein, S., Herayanti, L., \& Gunawan. (2015). Pengaruh Penggunaan Multimedia Interaktif terhadap Penguasaan Konsep dan keterampilan Berpikir kritis Siswa pada materi Suhu dan kalor. Jurnal Pendidikan Fisika Dan Teknologi, I(3), 221-225.

Irawan, R., \& Surjono, H. D. (2018). Pengembangan E-Learning Berbasis Moodle Dalam Peningkatkan Pemahaman Lagu Pada Pembelajaran Bahasa Inggris. Jurnal Inovasi Teknologi Pendidikan, 5(1), $1-11$.

Irwandani. (2016). Potensi Media Sosial dalam Mempopulerkan Konten Sains Islam. Tadris: Jurnal Keguruan Dan Ilmu Tarbiyah, 1(2), 173-177.

Kominfo. (2014). Hasil Survei Tanggal 18 Februari 2014.

Mahendra, B. (2017). Eksistensi Sosial Remaja dalam Instgram. Jurnal Visi Komunikasi, 16(1), 151-160.

Nasution, R. D. (2017). Pengaruh
Perkembangan Teknologi Informasi Komunikasi terhadap Eksistensi Budaya Lokal. Jurnal Penelitian Komunikasi Dan Opini Publik, 21(1), 30-42.

Nugroho, I. R., \& Ruwanto, B. (2017). Pengembangan Media Pembelajaran Fisika Berbasis Media Sosial Instagram Sebagai Sumber Belajar Mandiri Untuk Meningkatkan Motivasi dan Prestasi Belajar Fisika Siswa Kelas XI SMA. E-Jurnal Pendidikan Fisika, 6(6).

P, A. A. S. N. A., H, S. K., \& Wisodo, H. (2016). Penguasaan Konsep Siswa SMA pada Materi Suhu dan Kalor. Pros. Semnas Pend IPA Pascasarjana UM, 1, 1-5.

Paramita, A. D., Rusilowati, A., \& Semarang, U. N. (2016). Pengembangan Bahan Ajar Berbasis Literasi Sains Materi Suhu dan Kalor. Phenomenon: Jurnal Pendidikan MIPA, 58-67.

Prabowo, A., \& Arofah, K. (2017). Media Sosial Instagram sebagai Sarana Sosialisasi Kebijakan Penyiaran Digital. Jurnal ASPIKOM, 3(2), 256-269.

Putro, M. D., \& Litouw, J. (2018). Robot Pintar Pengukur Kepuasan Konsumen pada Pusat Perbelanjaan. Jurnal Teknologi Dan Sistem Komputer, 6(1), 25-31. https://doi.org/10.14710/jtsiskom.6.1 .2018.25-31

Saregar, A. (2016). Pembelajaran Pengantar Fisika Kuantum dengan Memanfaatkan Media PhET Simulation dan LKM Melalui Pendekatan Saintifik: Dampak pada Minat dan Penguasaan Konsep Mahasiswa. Jurnal Ilmiah Pendidikan Fisika Al-Biruni, 5(1), 53-60.

https://doi.org/10.24042/jpifalbiruni. v5i1.105

Sari, A. M., \& Gunawan, I. (2018). Developing Physics Monopoly 
Game Learning Media for Light and Optical Devices. Jurnal Ilmiah Pendidikan Fisika Al-BiRuNi, 7(1), 71-79.

https://doi.org/10.24042/jipfalbiruni. v7i1.2564

Sayyadi, M., Hidayat, A., \& Muhardjito. (2016). Pengaruh Strategi Pembelajaran Inkuiri Terbimbing dan Terhadap Kemampuan Pemecahan Masalah Fisika pada Materi Suhu dan Kalor Dilihat dari Kemampuan Awal Siswa. Jurnal Inspirasi Pendidikan, 6(2), 352-364.

Shamad, M. I. (2017). Pemanfaatan Teknologi Komunikasi dan Informasi dalam Pengembangan M.Ishaq Shamad Dakwah. Jurnalisa, 3(1), 16-30.

Sofyani Wigati. (2015). Pengembangan Youtube Pembelajaran Berbasis Ki Hadjar Dewantara untuk Materi Integrasi SMA. Jurnal Nasional Etnamatnesia, 3.

Sugiyono. (2018). Metode Penelitian Kuantitatif, Kualitatif dan $R \& D$. bandung: Penerbit Alfabeta.

Sulfemi, W. B., \& Mayasari, N. (2019). The Use of Audio Visual Media in Value Clarification Technique to Improve Student Learning Outcomes in Social Studies. Jurnal Pendidikan, 20(1), 53-68.

Sulistyono. (2016). Pemanasan Global (Global Warming) dan Hubungannya dengan Penggunaan Bahan Bakar Fosil. Forum Teknologi, 2(2), 47-56.

Widayanti, Abdurrahman, \& Suyatna, A. (2019). Future Physics Learning Materials Based on STEM Education: Analysis of Teachers and Students Perceptions. Journal of Physics Conferences Series, 1155, 19. $\quad$ https://doi.org/10.1088/17426596/1155/1/012021

Widayanti, \& Yuberti. (2018). Pengembangan Alat Praktikum Sederhana Sebagai Media Praktikum Mahasiswa. JIPFRI (Jurnal Inovasi
Pendidikan Fisika Dan Riset Ilmiah), 2(1), 21-27. https://doi.org/10.30599/jipfri.v2i1.1 61

Yuberti, Y. (2015). Online Group Discussion pada Mata Kuliah Teknologi Pembelajaran Fisika. Jurnal Ilmiah Pendidikan Fisika AlBiruni, 4(2). 